$920 I$

Audubon 




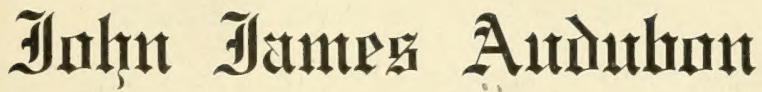

By Edward B. Clark.

DIRECTOR OF THE ILLINOIS AUDUBON SOCIETY


210944 


\section{The Spirit of the Great Naturalist.}

The simple truth is spoken when it is said that the Audubon societies formed for the protection of the wild bird life of America are carrying forward their work not only in the name of Audubon but in the spirit which was the great naturalist's guide. John James Audubon was a lover of nature. He made his way deep into the Mother's heart and there held his place through the long years of his life. Too little is known to the most of the American people of this man who, Frenchman by extraction, was wholly American in love and loyalty.

\section{Audubon the Dreamer.}

Some men have said that Audubon was an impractical man, a dreamer. Impractical he was and a dreamer too, but the world is better for its dreamers. The business man of large affairs looks with a sort of pitying arrogance upon the man who loves the woods rather than the counting house. The man who goes to the woods with a purpose in his heart has chosen the better part. The impractical Audubon will live when those who called him dreamer have been for centuries forgotten.

\section{Birth of Audubon.}

John James Audubon was born in St. Tammany Parish, Louisiana, about twenty miles from New Orleans some time between the years $17 \% 2$ and 1783 , the exact date being unknown. He was the son of Admiral Jean Audubon an officer of the French navy who served under Rochambeau in the fleet which aided America in establishing her independence. Admiral Audubon with his wife were visiting in Louisiana at the time of the birth of the boy who was destined to become the best known of all American naturalists. The boy Audubon's mother was killed in 1793 in Santo Domingo where her husband held a large landed property. Madam Audubon lost her life during one of the negro insurrections in that island. Admiral Audubon took his children to France where he remarried and gave his youngest son, John James, the only mother he ever knew.

\section{Audubon's Love of Birds.}

It is impossible in a brief sketch to tell the hundreth part of what there is to be told of Audubon's life. It was filled with interest from the hour of his birth on the shore of Lake Ponchartrain to the hour of his death in Audubon Park on Manhattan 
Island. From his earliest years Audubon showed a love for nature. His interest and his affection, for both were involved, turned particularly to birds. During his boyhood days in France as he has said himself "Instead of going to school when I ought to have gone I usually made for the fields." On these truant excursions he studied such birds, flowers, trees, pebbles and shells as a somewhat limited field of observation gave him opportunity.

Audubon's stepmother loved him devotedly and she did her best in a kindly mistaken way to spoil him, but he was of too fine a fiber to be spoiled by stepmother indulgence. His father knew the value of learning and while he had sense enough to be pleased with all that his boy had accomplished in the way of laying up a store of knowledge of the beasts of the field and the fowls of the air, he knew that in order to make these things tell in the world that other knowledge must bear them company. Audubon in later years was given an occasion to belittle his own education, but he had a greater store of learning than he was given to putting down to his credit. It is perhaps a clue to the nature of the man to say that as a pupil at school he loved geography and loathed mathematics.

\section{Audubon's Home in Pennsylvania.}

Audubon lived in France until he was approaching manhood. Then his father found it necessary to send him back to the United States of America which Audubon calls "my own beloved country," and he adds "I came with intense and indiscribable pleasure." It is necessary to pass over some of the experiences of the first few months in America. Years before, Admiral Audubon during a visit he had paid to Penisylvania, had purchased the farm of Mill Grove where the Perkiomen Creek empties into the Schuylkill River.

In one of Audubon's manuscripts preserved in printed form in the fine life of the naturalist "Audubon and His Journals," by Maria R. Audubon, his granddaughter, we read: "At this place (Mill Grove) and a few days only before the memorable battle of Valley Forge, General Washington presented him (Audubon's father) with is portrait, now in my possession; and highly do I value it as a memento of that noble man and the glories of those days."

Miss Audubon who edited the Journals of her grandfather puts the Latin word "sic" in parenthesis after the naturalist's allusion to the "memorable battle" of Valley Forge. Audubon was a little 
confused apparently as to that for which Valley Forge is noted in American history.

Audubon lived for a long time at the Mill Grove farm, and there he followed almost unremittingly his bird studies. He writes of this time, "The mill was also a source of joy to me, and in the cave, which you too remember, where the Pewees were wont to build, I never failed to find quietude and delight."

One day while Audubon was rambling the woods in search of birds William Bakewell, the owner of an estate adjoining the Mill Grove Farm called at the Audubon house and left an invitation for the young naturalist to come over to see him. Audubon at this time had the prejudices of the Frenchmen and also of most of the Americans of that period. Bakewell was an Englishman, and Audubon, foolish boy that he calls himself, because of his prejudice against any native of the "tight little isle," did not accept Mr. Bakewell's invitation until he was driven to do it. He called finally and the first person to greet him was the despised Englishman's daughter, a beautiful young woman who later became Audubon's wife, a devoted, self-sacrificing wife. The naturalist speaks of her as he first saw her in one of his letters to his sons: "Oh! may God bless her! It was she my dear sons, who afterward became my beloved wife and your mother.'

After living for some time at Mill Grove he returned to France where he stayed for two years. One of his first duties there was to gain his father's consent to his marriage. During this time in France as he says, "In the very lap of comfort my time was happily spent. I went out shooting and hunting, drew every bird I procured, as well as many other objects of natural history and zoology.'

\section{Birds Versus Business-Store in Kentucky.}

Much may be passed. Audubon returned to America and as a preliminary to marriage and acting under the advice of the father of his affianced, he tried to fit himself for a mercantile business, but it did not suit him. Birds not business were in his head. Before he had sailed for France he had begun a series of drawings of the birds of America and had begun a study of their habits. He was married in the year 1808 in Philadelphia and the next morning with his bride he left for Louisville, Ky. He still intended to follow a business career and with Ferdinand Rozier he opened a store in the Kentucky metropolis which as Audubon writes, "Went on prosperously when I attended to it, but birds were birds then as now, and my thoughts were ever and anon turning toward them as objects of my greatest delight." 
During the time that Audubon passed in Louisville he made constant excursions into the woods and fields. He was drawing birds and studying their habits in life constantly. His heart was with nature and the store was a burden. When he was forced to go to Philadelphia or New York to purchase goods he enjoyed the journeys only as he confessed as they afforded him the means "to study birds and their habits as I traveled through the beautiful, the darling forests of Ohio, Kentucky and Pennsylvania."

More than once Audubon allowed his pack horses "laden with goods and dollars" to become lost to sight and in danger of being lost beyond recovery while he stopped to watch the activities and to admire the colorings of some woodland warbler.

Pecuniary difficulties overtook the naturalist. He did not attempt as a man of steadier business method might have attempted, to find a really serious means of recouping his losses. In a letter he says: "Your mother was well, both of you were lovely darlings of our hearts, and the affects of poverty troubled us not." The naturalist continued to make his pictures of birds and quadrupeds and while his friends and relatives doubtless thought that his drawings and his forest excursions was a waste, possibly a willful waste of time, they proved to be the basis of his future fame.

\section{The Mill in Kentucky.}

The Audubons went to Henderson, Ky., and then there was a new business venture, a steam mill, which he declares to his sons in a letter was "of all the follies of man one of the greatest, and to your uncle and to me the worst of all our pecuniary misfortunes." Audubon worked hard at his mill but he called it afterward the "bad establishment." He parted finally with every particle of property to his creditors paying the last dollar that he owed and leaving Henderson with only his clothes and his original drawings. Of his wife he says that she felt the pangs, "of our misfortune but never for an hour lost her courage; her brave and cheerful spirit excepted all and no reproaches from her beloved lips ever wounded my heart. With her was I not always rich?"

\section{Drawing School in Cincinnati.}

Audubon as he expressed himself was not inclined to cut his throat in foolish despair. He resorted to his talents and for some time he drew portraits, managing thus to eke out a living, and still giving over as much time as he could to the drawing of birds. He obtained a position in a Cincinnati museum and he established a 
drawing school. The musemm authorities promised to pay him well but did not keep their promise.

\section{The Naturalist Removes to New Orleans.}

Finally the naturalist went to New Orleans. As Maria R. Audubon tells us "He had now a great number of drawings, and the idea of publishing these had suggested itself to both him and his wife."

Audubon was separated from his family for nearly a year being kept from sending for his wife and children because of the fear of yellow fever. He took a position as a tutor in the family of Mrs. Charles Percy of Bayou Sara. "Here the beloved Lonisiana whose praises he never wearied of singing, whose magnolia woods were more to him than palaces, whose swamps were store houses of treasures, he stayed till autumn, when all fear of yellow fever being over, he sent for his wife and son."

\section{In Philadelphia and New York.}

Poverty was the part of the Audubons while in the far south, but the naturalist kept up his hope and his cheer. March, 1824, found Audubon in Philadelphia where his drawings perhaps for the first time drew an attention which afterwards broadened and which finally led to the recognition which has lasted through the years. For a year he traveled through the woods and fields of New York and the country further west about the Great Lakes. Thence again he went to New Orleans intending from there to go to England. He had made in various ways, one of which was the teaching of dancing, about $\$ 2,000$ and with this and with some of the savings of his wife, money which she had put aside to forward the journey to England from which much was expected, he started for the other side of the water

\section{Audubon's Visit to England.}

It is impossible to give in detail the story of Audubon's visit to England. There he received encouragement for his work and recognition of his scientific researches. He published his great monumental work, the "Birds of America" in four Elephant folio volumes, representing 435 colored plates in life size figures. This undertaking covered the period of eleven years (182\%-1838). After becoming associated with William MacGillivray, the celebrated scotch ornithologist and anatomist, the "Ornithological Biography" to accompany the plates, was published in five volumes (1831-39). Mrs. Audubon who was with her husband rewrote the entire manuscript that it might be sent to America. 
In speaking of the association of Audubon with MacGillivray, Dr. Cones says, "The brilliant French-American naturalist was little of a 'scientist.' Of his work the magical beauties of form and color and movement are all his; his page is redolent of Nature's fragrance; but MacGillivray's are the bone and sinew, the hidden anatomical parts beneath the lovely face, the nomenclature, the classification-in a word the technicalities of the science."

Mr. and Mrs. Audubon spent some time in England and in Scotland and later went to the continent. The naturalist secured subscribers for his great work on the birds and this to him was the breath of life for it gave him the assurance of the means to continue in his chosen way.

\section{Returns to America.}

There is a sharp realization on the part of the writer of this that in the briefness of the sketch nothing at all adequate can be given touching the experiences of Audubon at this time. He came back to America and went on with his work. He made journeys into all parts of the American wilderness pursuing the work which he loved and which today the world loves him for. He explored Labrador and the prairies of the west. He knew the Everglades of Florida and the forests of the North. The breath of the forest were-his breath and the birds were his children.

\section{Greatest American Ornithologist.}

John James Audubon was the greatest of our American ornithologists for he was the one who gave inspiration to the study of the birds, and through all kinds of provocations and difficulties carried his study forward to success. "Just as sunset was flooding the pure, snow-covered landscape with golden light, at five o'clock on Monday, January $2 \%, 1851$, the 'pard-like spirit, beantiful and swift outsoared the shadow of our night."

\section{Audubon's Noblest Memorial.}

The writings and drawings of John James Audubon are a fitting monument to his memory, but his noblest memorial is to be found in the work of the societies formed for the protection of the wild bird life and which bear his name. 




Caylord $\bar{\equiv}$

Syracuse, N. Y. Srockion, Colif. 
